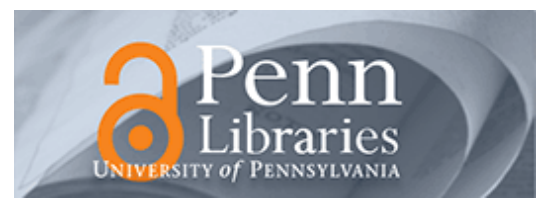

University of Pennsylvania

ScholarlyCommons

Management Papers

Wharton Faculty Research

$6-2013$

\title{
Capital Markets and Firm Organization: How Financial Development Shapes European Corporate Groups
}

Sharon Belenzon

Duke University

Tomer Berkovitz

Columbia University

Luis A. Rios

University of Pennsylvania

Follow this and additional works at: https://repository.upenn.edu/mgmt_papers

Part of the Management Sciences and Quantitative Methods Commons

\section{Recommended Citation}

Belenzon, S., Berkovitz, T., \& Rios, L. A. (2013). Capital Markets and Firm Organization: How Financial Development Shapes European Corporate Groups. Management Science, 59 (6), 1326-1343.

http://dx.doi.org/10.1287/mnsc.1120.1655

This paper is posted at ScholarlyCommons. https://repository.upenn.edu/mgmt_papers/234

For more information, please contact repository@pobox.upenn.edu. 


\title{
Capital Markets and Firm Organization: How Financial Development Shapes European Corporate Groups
}

\begin{abstract}
We investigate the effect of financial development on the formation of European corporate groups. Because cross-country regressions are hard to interpret in a causal sense, we exploit exogenous industry measures to investigate a specific channel through which financial development may affect group affiliation: internal capital markets. Using a comprehensive firm-level data set on European corporate groups in 15 countries, we find that countries with less developed financial markets have a higher percentage of group affiliates in more capital-intensive industries. This relationship is more pronounced for young and small firms and for affiliates of large and diversified groups. Our findings are consistent with the view that internal capital markets may, under some conditions, be more efficient than prevailing external markets, and that this may drive group affiliation even in developed economies.
\end{abstract}

\section{Keywords}

corporate groups, financial development, internal capital markets

\section{Disciplines}

Management Sciences and Quantitative Methods 


\title{
Capital markets and firm organization: How financial development shapes European corporate groups
}

\author{
Sharon Belenzon* $\quad$ Tomer Berkovitz ${ }^{\dagger} \quad$ Luis Rios $^{\ddagger}$
}

July 12, 2012

\begin{abstract}
This paper investigates the effect of country-level financial development on the formation of corporate groups. Since cross-country regressions are hard to interpret in a causal sense, we use exogenous industry measures to investigate a specific channel through which financial development may affect group affiliation: internal capital markets. Using a comprehensive firm-level dataset on European corporate groups in 15 countries, we find that countries with less-developed financial markets have a higher percentage of group affiliates in more capital-intensive industries. This relationship is more pronounced for young and small firms and for affiliates of large and diversified groups. Our findings are consistent with the view that internal capital markets may, under some conditions, be more efficient than prevailing external markets, and that this may drive group affiliation even in developed economies.
\end{abstract}

Keywords: corporate groups, financial development, internal capital markets

JEL Classification: G32, G18, O16

\section{Introduction}

This study seeks to deepen our understanding of firms' organization and boundaries by examining how regional institutional differences affect the propensity of firms to form groups within 15 Western European countries. We focus on one specific channel through which incentives to band together may operate: internal capital markets ("ICM"). ${ }^{1}$ In our setting, federations of firms (for example the German konzern) are usually referred to as corporate groups (Faccio, et al., 2009). We test and quantify the effect of ICM on group formation by ranking industries according to their level of external capital needs while also ranking countries according to their relative levels of financial development.

\footnotetext{
*Fuqua School of Business, Duke University (sharon.belenzon@duke.edu)

${ }^{\dagger}$ Columbia University, Graduate School of Business (tb2122@columbia.edu)

${ }^{\ddagger}$ Fuqua School of Business, Duke University (luis.rios@duke.edu)

${ }^{1}$ Section 2 relates our work to prior studies on groups and ICM (e.g. Khanna and Palepu, 1997; Khanna and Yafeh, 2005; Almeida and Wolfenzon, 2005; Cestone and Fumagalli, 2005; Morck, et al., 2005).
} 
Then we compare how the distributions of group-affiliated firms across industries vary across nations. Our empirical test is thus whether within-country differences in the probability of corporate group affiliation across industries are conditioned by the interaction between a firm's industry's dependence on external capital and its country's relative level of financial development.

The formation of groups is often viewed as an intermediating organizational response to missing or inefficient markets (Leff 1978). This is an appealing argument with important strategy and policy implications, but its examination poses three significant empirical challenges. First, while it predicts that group formation should be driven by market development, groups themselves may actually restrain the development of the institutions they mimic (Khanna and Yafeh, 2007). Thus, groups which may have arisen for reasons other than a response to inefficient markets may go on to hamper subsequent financial development by limiting arms-length transactions. Second, omitted or latent macro variables can be correlated with both financial development and the prevalence of groups. Third, group affiliates are often privately-held corporations under intricate ownership arrangements, rendering many groups "relatively invisible" (Granovetter, 1995). This is particularly likely in the face of regulatory pressure to be discrete about the internal reallocation of resources, which may be perceived as detrimental to minority shareholders (Scharfstein and Stein, 2000) or even anti-competitive. ${ }^{2}$

This paper is the first to tackle all three of these challenges. First, we mitigate the reverse causality concern by focusing on internal capital markets. If groups replace inefficient financial markets, we would expect (i) a higher probability of group affiliation within capital-intensive industries, where affiliates are more likely to benefit from a group's ICM, and (ii) this relationship to be stronger in countries with less-developed financial institutions. A pure reverse causality argument is unlikely to explain the interaction effect between these two since a country's financial development is constant across industries, and it is not likely to account for within-country systematic differences in group affiliation between high and low demand industries. We employ a difference-in-differences strategy to determine whether the difference in group affiliation between higher and lower external dependence industries is more stark for countries with lower financial development. Second, we develop a comprehensive dataset on group affiliation and financial information covering over 139 thousand (mostly private) European firms. Our estimation strategy allows us to substantially mitigate unobserved industry and country heterogeneity in addition to controlling for both country and industry fixed effects, by performing a more refined test of our theory that variation in the relationship between external dependence and financial development among our sample firms is consistent with the ICM theory.

\footnotetext{
${ }^{2}$ For example, in its rationale for blocking the Honeywell/GE merger, the EU Commission argued that GE's internal capital resources would give unfair advantages to Honeywell (case no. COMP/M.2220, p 83-84, July 2001).
} 
Third, to mitigate the invisibility problem, we construct detailed ownership and control hierarchies for groups by exploiting the strict reporting requirements of the EU, where both public and private firms have to file annual reports detailing ownership and financial information. Because ICM transactions themselves are hard to observe, we employ an indirect approach (e.g. Dahl, et al., 2002) to capture the impact of ICM. We identify conditions where internal capital should be more beneficial and systematically test whether these conditions are associated with higher propensity for firms to be organized in groups. One advantage of our indirect approach is that it relies on the revealed preferences of firms, rather than on reporting which may be polluted by firms' self-serving interests.

We follow the methodology employed by Rajan and Zingales (1998) to rank industries according to their dependence on external sources of funding, taking into consideration external funds dependence, external equity dependence, and trade credit. Then we rank the 15 West-European countries in our sample according to their level of financial development using world-bank indices which consider the stock market and banking systems for each country (Beck, et al., 2007). Though our focal countries are relatively wealthy and enjoy developed legal environments, they nonetheless exhibit measurably different levels of financial institution development according to these fine-grained indices. To supplement the accounting measures of financial development, we also use measures from the World Economic Forum, Executive Opinion Survey, 2006-2007 (Claessens and Laeven 2003), which capture local access to equity and loan markets.

Our findings strongly support the ICM hypothesis. We find that high-dependence industries have disproportionately more group affiliated firms than low-dependence industries, and that this difference declines as financial development increases. This result suggests that less-developed markets disproportionately foster the formation of corporate groups in sectors where internal capital markets are especially beneficial. Consistent with the view that small and young firms are likely to face higher costs for outside capital (Gompers 1995), our results also show that the effect of financial development on group affiliation is more significant for smaller and younger firms. Our results are also strong for firms affiliated with larger and more diversified groups, where ICM are likely to be more substantial.

\section{Corporate groups and internal capital markets}

\subsection{What are European Corporate Groups?}

Our paper focuses on a set of West European economies which: i) share a clear and consistent definition of groups based on historical, institutional, and economical traditions; ii) exist within a narrow enough range of economic development, so that we do not commingle developing and developed economies; 
and iii) have enough variation in their financial development and industries, so that we may observe the impact of a meaningful interaction between industry capital demand and country economic development.

Group definition is important in our study because there are many incongruous conceptualizations of what a group is. Since Leff's seminal work (1978), scholars have found many different examples of "firms bound together in some formal and/or informal ways, characterized by an 'intermediate' level of binding" (Granovetter, 1995, page 95). Mostly within the context of emerging economies, the business group literature has emphasized features such as concentrated ownership, reciprocal trading arrangements, and familial control, (Khanna and Rivkin, 2001, 2006; Kester, 1992). Concurrently, the "pyramidal groups" literature has focused mainly on formal ownership structure and the often darker sides of group organization within developed economies (Almeida and Wolfenzon, 2006; Morck, 2005).

We do not take a position on whether these streams speak of the same phenomena, and we do not claim that our empirical sample overlaps directly with any of these types of groups. Rather, we rely on the ownership-based EU definition of groups to ensure the consistency of criteria needed for our empirical strategy. The concept of corporate groups within a Western European context is codified in legal, cultural and economic institutions, and this reduces our dependency on theory for assumptions about boundary conditions for group membership. ${ }^{3}$ Thus, our concern in this paper is not so much with showing whether groups exist in Europe, as it is to explore whether the heterogeneity in their prevalence across countries and industries provides evidence of an ICM mechanism behind their formation.

Though prior work has found ownership links to be tepid determinants of group membership in emerging markets (Khanna and Rivkin, 2006), there are strong reasons to believe that they reliably demarcate group membership in our setting. In the EU, courts and government agencies specifically emphasize the concept of control as a condition for group affiliation. This refers to the direct and indirect ownership stakes the controlling shareholder has in each of the corporate group affiliates (Windbichler, 2000). Additionally, the notion of corporate groups is part of the economic environment in the EU. For example, Figure 1 shows the ownership structure of a representative group, Berge y Cia., which describes itself as "one of the major Spanish corporate groups." 4 Similarly, a vast number of firms in our sample incorporate group membership into their corporate identity, by including the

\footnotetext{
${ }^{3}$ Direct references to corporate groups are found throughout the EU governing documents, for example the Fourth Directive of the Council of European Communities (1978), where accounting reporting regulations for groups are stipulated: "Whereas, when a company belongs to a group, it is desirable that group accounts giving a true and fair view of the activities of the group as a whole be published."

${ }^{4}$ Obtained from Berge corporate website main page: http://www.bergeycia.es
} 
word "group" in their letterhead, websites, and logos, in addition to references to other group members in their marketing materials.

The EU definition is also consistent with much academic work which focuses on corporate groups (e.g. Deloff, 1998; Morck, 2005; Smagns, 2006; Cestone and Fumagalli, 2005). Following Faccio, et al., (2009), we classify a firm as a group affiliate if it satisfies at least one these three criteria: i) the firm is a subsidiary (that is, it has a controlling parent company), ii) it controls another firm; iii) it has the same controlling shareholder as at least one other firm.

It is important to note that we do not attempt to capture every single firm or group within our region of study. However, for our empirical strategy to work, it is paramount that our sampling is representative of the distribution of industries within a given country, along the dimensions of external dependence and country financial development, and that it is not biased by firms that are missing ownership or financial information. For this reason, we exclude very small firms from our main estimation sample, whose ownership and financial data is not consistent across countries. Section 3 details our specific data construction and method for characterizing firms as group affiliates, including a detailed discussion of our mitigation of potential bias issues. We perform a battery of tests to ensure that our results are robust to alternate sample inclusion criteria.

Our focused empirical approach may limit the generalizability of our study, since groups (in the broader context) are heterogeneous across time and place (Khanna and Rivkin, 2001). Nonetheless, because our study focuses on how relative market efficiency drives the partial internalization of transactions within groups, our findings should be relevant in other settings where "the group is an integral part of the resource allocation mechanism," (Goto, 1982, p. 60). As well, we document conditions under which financial capital may be a valuable resource even in developed economies.

\subsection{Internal capital markets}

ICM have been observed within loosely tied groups as well as vertically integrated conglomerates, albeit for reasons that vary (e.g. Perotti and Gelfer, 2001; Cestone and Fumagalli, 2005; Gopalan, et al., 2007). For example, Carney et al.'s 2011 meta-study of the broad group literature found that financial infrastructure development generally moderates group affiliation negatively, which lends support to the ICM hypothesis. Similarly, ICM have been found to lower the cost of capital for many types of groups and give them access to financial institutions (Khanna and Palepu, 1997; Gertner, et al., 1994; Weinstein and Yafeh, 1998). ICM need not arise solely as a response to missing or signif- 
icantly underdeveloped markets. ${ }^{5}$ Even in countries with well-developed financial institutions, ICM can still improve access to favorable capital market conditions (Cetorelli and Goldberg, 2012), mitigate asymmetric information between firms and capital sources (Myers and Majluf, 1984), or provide better governance mechanisms via ownership than would be possible under lending relationships (Wulf, 2009). Furthermore, these are likely to be more pronounced within countries where financial institutions are less sophisticated and information and transparency are reduced, even if overall capital liquidity is not substantially lower.

However, direct evidence of ICM remains scarce, especially within European corporate groups (de Haas, et al., 2010). Often, ICM transactions occur between sophisticated corporate group members, and involve valuable yet intangible resources such as loan guarantees or deposit smoothing (Cremers, et al., 2010), which are inherently difficult to observe and quantify. Therefore, ICM is often documented through inference, for example by observing correlated credit patterns (e.g. Dahl, et al., 2002) or relying on financial statement analysis (Deloof, 1998).

Within the relatively developed countries in our study, we would expect ICM to work through subtle mechanisms like the direct funding of affiliates using cash flow from other affiliates with less attractive investment opportunities, or the leveraging of group reputation and assets as guarantees for the capital raising efforts of affiliates. Often, a corporate group may have financing subsidiaries in various markets, which are able to raise capital on favorable terms as a result of guarantees provided by the controlling firm. For example, Novartis' subsidiaries regularly issue debt that is guaranteed by the parent, such as a $\$ 2$ bn issue by Novartis Capital Corp., the $\$ 3$ bn issued by the group's Bermuda unit, Novartis Securities Investment, and the EUR 1.5bn issued by Novartis Finance (Luxemburg). In all three cases, the debt was guaranteed by the parent, and accompanied by statements which obliquely acknowledged the ICM nature of these transactions, such as: "proceeds will be used for intercompany refinancing purposes in connection with the pending Alcon acquisition, as well as for general corporate purposes."

Our central question is whether the ICM that have been observed reflect beneficial side effects of groups (which may form for a variety of reasons) or whether the benefits of ICM themselves foster group formation. To properly address this, we systematically document the distributions of groups across industries and countries. Quite simply, we look for groups to be more prevalent wherever ICM would be more valuable.

\footnotetext{
${ }^{5}$ An issue beyond the scope of this paper is whether companies could "migrate" to the most efficient financial environments within Europe and circumvent the deficiencies of their home country systems. The current concensus on firm mobility in Europe is that it is still rare, as it is largely constrained by taxation and jurisdiction issues. See Bratton and McCahery (2009).
} 


\section{Methods}

\subsection{Empirical strategy}

We study the effect of financial development on group affiliation by testing whether corporate groups substitute for less developed financial institutions. Here, reverse causality between group formation and financial development poses a serious identification challenge. This is because we might expect lower overall incentives for financial markets to improve in regions where groups already facilitate financing. Thus, groups may actually hamper financial development, rather than be a response to lower development. An additional issue is that simply examining firm-specific proxy for external financial dependence would measure external funding set in equilibrium rather than the demand for external funding, and thus suffer from endogeneity problems. The use of aggregate and exogenous industry variation should be especially advantageous in this setting.

To deal with these issues, we analyze a key channel through which financial development affects group affiliation: internal capital markets. If groups form as a substitute for underdeveloped financial markets, we should observe a higher probability of group affiliation for firms with a higher external financing needs, since they would benefit more from access to internal capital markets. This should be more pronounced in countries with relatively low financial development since these countries have more limited alternatives to raising capital. We follow the methodology of Rajan and Zingales (1998) and rank industries according to the extent that they rely on external funds by looking at U.S. firms.

The logic behind this strategy is this: (i) The U.S. is the most advanced capital markets in the world, where publicly-traded firms face the least friction in accessing finance. Thus, the amount of external finance used by these companies is a good measure of their industry's demand for external finance. (ii) Disclosure requirements result in comprehensive data on funding sources. (iii) U.S. industry data is exogenous to European firms, but major industries are structurally similar, so an industry's dependence on external funds in the U.S. is likely to be a good measure of that industry's dependence on external funds in our setting; (iv) groups are less common in the U.S., so U.S. firms' demand for external funds is a good proxy for demand in the absence of options for group ICM's.

Two main assumptions are needed for our identification strategy to work: that technological differences explain why some industries rely on external funds more than others, and that these differences persist across countries.

Figure 2 shows the logic behind our empirical strategy. We can readily see that nations with lower scores in terms of stock market development also have considerably larger shares of group-affiliated firms in industries with high external capital dependence. We define the measures used in the next 
section. Though in our regressions we introduce a number of controls to better understand these relationships, this non-parametric pattern is prima facie consistent with the hypothesis that groups provide an alternative source of capital within less developed financial markets.

\subsection{Data}

Our dataset relies on detailed ownership links and accounting information from the 2007 version of Amadeus, a comprehensive European database by Bureau van Dijk (BVSD), which covers both private and public firms. BVD has developed a format that standardizes financial items across the various countries' filing regulations, balanced with a realistic representation of European company accounts. A key advantage of these data is that by including private as well public firms, we capture a wide range of firm sizes. In this paper we mostly exploit cross-sectional variation, across firms, industries, and countries. Because Amadeus includes information for industrial firms only, we add information for financial institutions from BankScope, which provides ownership information for about ten thousand banks. The final estimation sample includes 139,254 firms, $50.6 \%$ of which are affiliated with 26,711 groups. ${ }^{6}$

\subsubsection{Sample construction}

In this section, we explain our three-step methodology for constructing the data and describe our sample. We first identify which of the dyadic inter-firm ownership links reported in Amadeus or BankScope represent a controlling interest. Then we use this information to map hierarchies of ownership and infer group structure. Finally, we reclassify or drop some firms and groups according to a set of refining criteria.

Ownership links. To ensure that the ownership links we observe represent actual control, they must include a minimum share of voting rights. For private firms, a link is considered controlling if it has at least $50 \%$ of the voting rights. For public firms, which typically have a more dispersed ownership, the threshold is set at 20\%, consistent with previous literature on public firms (e.g. La Porta et al. 1999, Faccio and Lang 2001). Our results are not sensitive to different plausible specifications of these thresholds. It is important to note that links between firms need not be direct. For example, if firm A owns $50 \%$ of firm B, and firm B owns $50 \%$ of firm C, then firm A has a $25 \%$ ownership link to C.

Corporate group definition. We define a corporate group as a set of at least two legally distinct firms where one of them is a controlling ultimate owner according to the ownership links identified above. Specifically, this means that for a firm to be a group affiliate, it must meet at least one of these

\footnotetext{
${ }^{6}$ One has to be cautious when comparing these percentages with previous studies on business groups (e.g., La Porta et al. 1999, Faccio and Lang 2002) because our sample includes private firms; previous studies focused on public firms.
} 
criteria: i) the firm is a subsidiary (that is, it has a controlling parent company), ii) it controls another corporation; iii) it has the same controlling shareholder as at least one other corporation.

Estimation sample selection. We impose two additional conditions before finalizing our baseline estimation sample. First, banks are excluded, as they are likely to face different considerations when joining groups (the affiliation decisions of financial institutions are beyond the scope of this paper). Second, countries in our sample differ in their reporting requirements for small firms, because countries have different mandatory filling requirements for them. Thus, many small firms simply do not file reports in some countries. There is, however, no reason to suspect within-country systematic variation in reporting patterns across industries. Since our empirical approach investigates the interaction between industry and country measures, while controlling for country and industry level effects, our results are not sensitive to cross-country variation in reporting patterns. Nonetheless, we mitigate the potential bias of voluntary disclosure by eliminating all firms that generate less than $\$ 10 \mathrm{~mm}$ in annual sales. This is a conservative threshold based on our research on BVD's data collection processes, which included multiple interview with their experts and top executives. We perform a number of robustness checks to ensure that our size thresholds do not introduce sample bias.

\subsubsection{Industry external dependence}

In order to thoroughly explore the interactions between financial development and external dependence, we use multiple measures of each, and interact them in multiple combinations. For external dependence we use three distinct measures. External funds dependence is calculated by dividing the cost of capital expenditures, in excess of cash flows from operations, over the total cost of capital expenditures. This captures the fraction of the firm's investment that are not financed using internal cash flows. We also follow Nilsen (2002) and Fisman and Love (2003) and focus on suppliers' provision of funds - trade credits. We construct trade credits as the ratio between accounts payable and total assets. Finally, we take into account investment intensity, computed as capital expenditures over total assets. All measures are calculated using American Compustat firms from 1980 to 2000 at the three-digit SIC level (163 industries).

\subsubsection{Financial development}

We use four accounting measures and four survey measures of financial development. Our use of the word "development" in this context is consistent with much extant work. Nonetheless, some scholars may consider the differences we measure as capturing different "types" of development, eschewing the ordinal connotations implied by terms such as "level of development" (Carlin and Mayer, 2003). Thus, 
we are careful to point out that whether a country's level of development along any measure is higher or lower merely reflects whether a channel is more or less conducive to industrial firms' access to external capital. $^{7}$

To capture the relative development of various types of financial institutions within a country we rely on world-bank indices (following Beck, et al., 2007), which reflect the development of a country's stock markets and banking systems. An important part of our empirical approach hinges on independently evaluating the interaction of each of these measures with the measures of external capital dependence. This is because our various measures for development need not be perfectly correlated-for example a country may have an exceptionally well-developed banking system, but stock markets that are only average relative to other countries. Therefore, a composite measure of development which aggregates all measures might obscure important variation.

For stock market development, we use (i) stock market value/GDP, and (ii) capitalization and stock market capitalization/GDP. Stock market value is defined as the value of total shares traded on the stock exchange (a "flow" measure aiming at capturing stock market liquidity), and stock market capitalization is defined as the value of stocks listed on the stock market, aiming at capturing the size of production organized in publicly listed firms. For the banking system, we use private credit/GDP, the ratio of private credit by deposit money banks and other financial institutions to GDP, and bank deposits/GDP, the ratio of bank deposits to GDP, where bank deposits are the demand, time, and savings deposits in money banks.

Our four survey-based measures come from the 2006-2007 World Economic Forum Executive Opinion Survey (Claessens and Laeven 2003), which capture access to equity and loan markets. Access to loan market is based on the question: How easy is it to obtain a bank loan in your country with only a good business plan and no collateral? Financial system sophistication is based on the question: How sophisticated are the financial markets in your country? Access to venture capital is based on the question: In your country, how difficult is it for entrepreneurs with innovative but risky projects to find venture capital? Access to equity market is based on the question: How difficult is it to raise money by issuing shares on the stock market in your country?

\subsection{Descriptive statistics}

Panel A of Table 1 provides summary statistics for firms and groups in our sample. On average, our firms (including affiliates and standalones) have 392 employees (77 median) and generate $\$ 173$ million in annual sales (\$28 million median). Panel B reports corporate group characteristics. Our sample

\footnotetext{
${ }^{7}$ We thank an anonymous reviewer for this suggestion.
} 
firms belong to 26,672 unique groups with 12 affiliates on average. Groups in our sample have abundant resources: the average group holds around $\$ 6.5$ billion in assets, however this seems to be driven by groups at the highest end of the distribution, since the mean is $\$ 52$ million, and the 90th percentile is $\$ 1$ billion.

Table 2 presents summary statistics separately for affiliates and standalone firms. Affiliates tend to be larger in terms of the number of employees, sales, total assets, and cash flow, but quite similar in terms of age. In our econometric tests, we check whether very large firms in our sample are driving the results.

Table 3 presents the variation in external dependence for a number of industries. Examples of high external dependence industries include chemicals, research and development, information technology and drugs, while low external dependence industries include concrete, metal and minerals, textile, and transportation equipment.

\subsection{Econometric specification}

We estimate a Linear Probability Model for the likelihood that a firm is affiliated with a group. The econometric specification is:

$$
\operatorname{Pr}\left(\text { Affiliate }_{i}=1\right)=\beta_{1} \text { Sales }_{i}+\beta_{2} \text { FinDev }_{c} \times \text { ExtDep }_{j}+\beta_{3} \text { Sales share }_{j c}+\varphi_{j}+\eta_{c}+\epsilon_{i}
$$

$i$ denotes firms - the unit of observation, Sales $i$ is annual sales of firm, FinDev is $_{c}$ the financial development measure for country $c, \operatorname{ExtDep}_{j}$ is a measure of external dependence for industry $j, \varphi_{j}$ and $\eta_{c}$ are complete sets of industry and country dummies, and $\epsilon_{i}$ is an iid error term. Similar to Rajan and Zingales (1998), we control for the share of industry sales in each country. Sales share jc $_{c}$ is the share of total sales of industry $j$ (in which the focal firm operates) in country $c$. This measure is computed using all firms in the complete sample where we make no restrictions on sales volume.

Consistent with the hypothesis that the difference in share of affiliated firms between high and low external dependence industries would be larger in countries with lower financial development, we expect $\widehat{\beta}_{2}<0$. The interpretation of $\widehat{\beta}_{2}$ can be easily explained in terms of difference-in-difference. Taking the first difference in probability of affiliation with respect to external dependence, holding country financial development fixed, yields $\Delta P_{c}=\widehat{\beta}_{2}$ FinDev $v_{c} \times \Delta E x t D e p$. Next taking the difference in $\Delta P_{c}$ between high and low country financial development yields $\Delta P=\widehat{\beta}_{2} \Delta$ FinDev $\times \Delta$ ExtDep. Therefore, $\widehat{\beta}_{2}$ measures how much higher the likelihood of affiliation is at high level of external dependence with respect to an industry at low dependence level when the firm is located in a country with a high level of financial development rather than in a country with low level of development. In the tables that 
present the estimation results we refer to $\Delta P$ as the differential in affiliation probability. This is our main metric of quantification. In our regressions, differential in affiliation probability measures how much higher the likelihood of affiliation is at the 90th percentile level of external dependence with respect to an industry at the 10th percentile level when it is located in a country with the highest level of financial development rather than in one with the lowest level of financial development.

\section{Estimation results}

\subsection{Baseline estimation}

Table 4 reports the baseline estimation results for the interaction between financial development, using the World Bank accounting measures of stock market and banking system, and industry external dependence. The pattern of results is consistent with our hypothesis: the coefficient estimate on

the interaction terms between industry external dependence and country financial development $\left(\widehat{\beta}_{2}\right)$ is negative and highly significant for the various combinations of dependence and development. In unreported results we find that a similar probit specification yields consistently similar findings. Table 5 presents the estimation results using the survey measures. For each specification we calculate and report the differential in affiliation probability $(\Delta P)$.

The estimated effect of financial development on group affiliation varies for different development measures, ranging from a -11.9 percent for stock market capitalization to -2.6 percent for bank deposits. However, most measures have an effect between -5 and -8 percent, compared to a sample mean of affiliation of 50.5. Table 5 finds similar, though somewhat smaller estimates for the survey-based measures of financial development. We suspect that the survey measure may be noisier than the direct measures, resulting in some attenuation bias.

An important concern is that industry specialization may be systematically related to country financial development. For example, countries may specialize in certain industries as a response to the level of financial development. If this were the case we would expect economic production to be heavily concentrated in specific industries. We check the sensitivity of our results to such potential industry specialization by excluding industries with country sales share of above 2.5 percent - the 75 th percentile of the industry sales share distribution. The results are not sensitive to dropping dominant industries. For instance, estimating specification 1 of Table 4 yields as coefficient estimate of -0.023 (a standard error of 0.004) on the interaction term between stock market value and external funds dependence.

Our results are also robust to excluding very large firms using various different size thresholds. 
Estimating specification 1 in Table 4 using the sample where we remove firms with more than $\$ 100 \mathrm{~mm}$ in annual sales yields even stronger results compared to the baseline sample where we do not restrict the sample of maximal sales. Under these conditions, the coefficient estimate on the interaction between stock market value and external funds dependence is -0.023 (a standard error of 0.004). The next section further investigates how our results vary by firm size.

\subsection{Firm age and size}

We next explore whether the variation in country-industry interactions for different firm and group subsamples is consistent with the ICM theory. We focus on two fundamental firm characteristics: size and age. Stock market development is likely to play an important role in financing smaller and private firms for three main reasons. The first is direct financing, since smaller firms with insufficient collateral often have a hard time raising debt money via secured financing. ${ }^{8}$ The second reason is that stock market development increases private equity, venture capital funds, and angels, as these investors' exits rely on IPOs and divestitures, which are both positively correlated with stock market activity (Black and Gilson, 1998; Celikyurt, \& Sevilir, 2010). The third reason is through competition effects. In countries with less-developed equity or debt public markets, small and young firms have to compete for capital with more established firms. Assuming that the supply of capital is limited, as clearly demonstrated during the 2008 financial crisis, raising capital would be harder for small and young firms in less-developed financial markets.

Small and young firms should have on average more to gain by accessing a group's ICM under conditions of lower external financial development. Small firms typically do not have substantial internal resources, thus that are more likely to rely on outside capital to finance their operations and compete in the market place (Ernst, 1998). Young firms face the "liability of newness" (Freeman, et al., 1983) and are typically more dependent on external financing than older firms (Levinthal, 1991; Rajan and Zingales 1998). Firm age is commonly associated with higher levels of asymmetric information between the firm and outsiders, such as lenders (Ritter 1984, Oliner and Rudebusch 1992). Thus, the ICM theory predicts that the country-industry interactions would be particularly strong when comparing small standalone firms to small affiliated firms, compared to when comparing large standalone firms to large affiliated firms. The same reasoning applies to the respective comparison by

\footnotetext{
${ }^{8}$ The London Stock Exchange Alternative Investment Market (AIM) is one example of how stock markets provide direct financing for small firms. It allows small firms (average market capitalization of $\$ 65 \mathrm{~mm}$ relative to $\$ 1.1 \mathrm{bn}$ in the NASDAQ) to raise equity financing in the stock market. More than 3,000 firms have raised financing through the AIM. Between 1995 and 2008 this amounted to 64.4 billion GBP, and averaged 21.6 million GBP per firm. The importance of AIM for small firm financing was especially clear during the 2008-2009 global financial crisis, as 138 firms were still able to raise 8.5 billion GBP.
} 
firm age.

The results are consistent with these conjectures. Table 5 presents the estimation results for breaking the sample by quartiles of firm sales and quartiles of firm age. In columns 1 and 2 we see a large and significant coefficient on the interaction between industry dependence and country development for small and medium firms (first quartile of sales, with average sales of $\$ 12.6 \mathrm{~mm}$ and second to third quartiles, with average sales of $\$ 31.4 \mathrm{~mm})$. The differential effect for small firms is -6.9 and for medium-size firms it is -8.9 percent. In sharp contrast, the interaction effect is effectively zero for large firms (fourth quartile of sales; average annual sales of $\$ 616 \mathrm{~mm}$ ).

The large firm sample includes very large firms, which are almost always affiliated with a group. In unreported specifications we examine whether the lack of results for the large firm sample is driven by outliers by dropping all firms that generate more than $\$ 100 \mathrm{~mm}$ in annual sales. This exclusion reduces average sales for the large firms from $\$ 616 \mathrm{~mm}$ to $\$ 80.3 \mathrm{~mm}$. The industry-country interaction remains insignificant (a coefficient estimate of -0.010 and a standard error of 0.011 ). Thus, we conclude the lack of significant results for large firms is not driven by the presence of very large firms in this subsample.

In columns 4-6 we report very similar findings for firm age. For young and middle-age firms the coefficient estimate on industry-country interaction is large and is highly significant; however, it is completely muted for mature firms.

\subsection{Group size and industry diversification}

We next examine how our results vary by different group characteristics. We focus on group size and industry diversification as measures of the potential internal resources available to affiliates. Intuitively, larger size can be associated with more resources, while diversification is less straightforward. Diversification is likely to be positively associated with a more active ICM because a group with affiliates in diverse industries is more likely to have a mix of low capital-intensive affiliates from which to appropriate (supply) and high capital-intensive affiliates with better investment opportunities (demand). Of course, from a purely risk-sharing perspective, groups with homogenous affiliates would still provide ICM benefits as long as any external shocks affect some but not all affiliates. Nonetheless, redistributive benefits should accrue especially to diversified groups.

Group size and diversification are often related, with larger groups more likely to be more diversified. Thus, as with the size/age effects we discussed in the prior section, we do not fully disentangle the role of large groups vs. the role of diversified groups. Nonetheless, we expect both large and diversified groups to be attractive to potential affiliates in high dependency industries, so these effects should move in the same direction. Columns 7-9 in Table 6 break the sample to separately compare standalone firms 
to affiliates of small, medium and large groups (based on total group assets quartiles, with Q2 and Q3 considered "medium). The pattern of results is consistent with the ICM theory. The industry-country interaction is zero when comparing standalone firms to affiliates of small groups, but it is large for affiliates of medium and large groups (a coefficient estimate of -0.016 and a standard error of 0.005 , for both group categories, with differential effect of $-5.3 \%$ ).

We find the same pattern of results in Columns 10-12, where we split the sample by group industry diversification. For specialized groups (where all group sales are within a single three-digit SIC code), the coefficient estimate on the industry-country interaction is insignificant, but for medium and highly diversified groups the interaction is large and significant (differential effects of $-5.6 \%$ and $-5.3 \%$, respectively).

There is evidence that banks play an important role in ICM dynamics. 272 of our groups (which together have 3,105 affiliates) include a bank. We examine the distribution of these banks by group size and industry diversification. 58 percent of the banks belong to groups in the highest size (assets) quartile, while only 5 percent of the banks belong small groups in the lowest quartile. A less extreme pattern holds when examining bank distribution by group diversification, with 42 percent of banks belonging to groups in the top quartile of diversification. These patterns would be consistent with the view that the observed patterns of affiliation to large groups may also be related to the presence of banks in these groups. Evidence that the industry-country interaction estimates are driven by groups with specific types of financial institutions would strengthen our argument of ICM. It would also provide more clarity on the mechanism through which the group ICM is accessed by affiliated firms. However, such fine-grained analysis is beyond the scope of our paper. Future work should focus on not just banks, but also other types of cash-cow firms such as life insurance and utility companies, which may be prevalent in large corporate groups, and may provide steady sources of capital to affiliates.

\subsection{Robustness checks}

Table 7 presents estimation results for several robustness tests. First, we include the linear effect of external dependence, by not controlling for industry fixed effects. As expected, the interaction effect between external dependence and development remains negative and significant and the level effect is positive and significant. Then we explore whether the effect of countries' financial development on affiliation may vary non-linearly across industries' external dependence by splitting industries into quartiles of external dependence and interacting each quartile dummy separately with our external dependence measure (Table 7, column 2). We find negative and significant interaction coefficients for Q2 to Q4 (relative to the baseline, Q1). However the coefficient for the highest quartile of external 
dependence is almost twice that for the second and third quartiles.

When we exclude acquired firms that have been with the group less than five years (Column 3), we find the coefficient for the financial development and industry dependence interaction to be moderately larger than the baseline. This would be consistent with a view where long-term ties are more conducive to ICM.

In columns 4-7 we investigate the robustness of our results to different samples of Compustat firms. Listed U.S. firms tend to be large and operate in more than one industry. Thus, measuring industries' external dependence using diversified firms may be noisy. We use Compustat line-of-business data to characterize the extent to which firms operate in more than one three-digit industry code. The results remain robust for including only specialized firms (Column 4). In Columns 5 and 6 we calculate the external dependence measures based on firms with below and above median years since IPO. The results remain similar for both firm samples.

In our main specifications, we restrict our sample to firms that have at least $\$ 10$ million in sales. This is to ensure that we concentrate on firms that are unlikely to shirk on their reporting responsibilities. However, we also check our results by including all firms regardless of sales volume (increasing the sample to over 815 thousand firms). As shown in Column 7, the same pattern of results continue to hold. Actually, the coefficient estimate on the industry-country interaction and respective differential effect are larger in the unrestricted sample, as compared to baseline estimation sample (where firms are required to have at least $\$ 10 \mathrm{~mm}$ in annual sales). In Column 8 we restrict the sample to firms that generate at least $\$ 1 \mathrm{~mm}$ in annual sales. The results continue to hold.

Lastly, Column 9 addresses a different selection concern: the availability of ownership information. Our baseline sample excludes firms with no ownership information. These firms are likely to be standalones, as ownership coverage tends to be much better for firms that are affiliated with groups, even when the firms themselves are small. If the availability of ownership information systematically varies by industry external dependence and country financial development, our results may be biased. To check whether our results are sensitive to missing ownership information, we add to our baseline sample also firms with no ownership information, which we classify as standalones. As shown in Column 9, there is no substantial change in the estimated coefficient on the industry-country interaction. This strongly suggests that ownership information does not systematically vary along the external dependence and financial development dimensions. We repeat the same procedure for an unrestricted sample (not reported in the table). We include all firms in the Amadeus database with non-missing ownership information, totalling 1.9 million firms (of which 8.4 percent are group affiliated). We estimate the same specification as in Column 9 using this very large sample and find the same coefficient 
estimate (-0.018 and a standard error of 0.002$)$.

In unreported estimations, we address the concern that our findings are driven by specific countries. Using our baseline specification, we systematically remove each country in our sample (one at a time) and find that overall no single country drives our results. The coefficients on the interaction between stock market value/GDP and external funds dependence are very consistent, ranging from -0.017 to -0.026. All estimations yield significant and comparable differential effects.

\subsection{Panel estimation}

We estimate a panel specification of the effect of financial development on affiliation probability in order to control for country-industry effects. As discussed in Section 3.3, the descriptive statistics do not suggest any systematic skewness across countries in the distribution of firms high and low external dependence. Nonetheless, we employ a panel estimation approach to further ensure that the overall distribution of firms operating in high and low dependence industries is not systematically correlated with a country's level of financial development. Thus here we exploit time variation in country financial development.

Our approach investigates whether new firms are more likely to be established as standalones or affiliates when financial markets become more developed, especially in industries with high external dependence. Our unbalanced panel from 1980 to 2007 starts with the 2007 ownership structure and use $M \& A$ data to determine whether firms were incorporated as standalones or as affiliates. Firms can change their ownership structures either by joining a group or by separating from one, so the M\&A history helps us trace back to the structure of the firm at incorporation.

We make the following assumptions: For firms that appear as standalones in 2007, we assume that they were incorporated as standalones unless our M\&A data indicate the firm has divested of affiliates in the past, in which case it is reclassified as group-incorporated. For firms that are classified as affiliates in 2007, we assume that they were incorporated as affiliates of the same group unless we find evidence of having joined a group post incorporation.

We use BVD's Zephyr database and SDC Platinum to identify about five thousand firms that joined groups in our sample in 1980-2007. Our econometric specification is:

$$
\operatorname{Pr}\left(\text { Affiliate }_{i}=1\right)=\beta_{1} \text { FinDev }_{c t} \times \text { ExtDep }_{j}+\varphi_{j c}+\tau_{t}+\epsilon_{i t}
$$

Where $\varphi_{j c}$ and $\tau_{t}$ are complete sets of industry $\times$ country and year of incorporation dummies, respectively. FinDev $c$ is country $c$ level of financial development at year of incorporation $t$. Stock market value is available for 1988-2006, and private credit is available for 1980-2006. Because sales 
information is available only for the period 1997-2006, we do not control for firm sales. However, the results are robust to controlling for average firm sales, firm-maximum sales (the highest level of the sales the firm obtained in the period 1997-2006), and firm-year sales (conditioning the sample period to $1997-2006)$.

Table 8 presents the estimation results. The general pattern of results continues to hold. For financial development (stock market value), controlling only for linear industry and country effects, the coefficient on the interaction with external equity is -0.052 and is highly significant (with a standard error of 0.005$)$. Controlling for industry $\times$ country effects only slightly lowers the coefficient estimate (0.047), which remains highly significant. We find even stronger results for bank credit/GDP. Controlling for industry $\times$ country effects, this coefficient estimate increases to -0.091 , and is highly significant. These results imply that as financial markets improve over time, new firms are more likely to be established as standalones, rather than as corporate group affiliates.

We perform a number of robustness tests on our panel estimation, in line with those reported in the previous section. We find that reducing the sales threshold from $\$ 10$ million to $\$ 1$ million has a negligible effect (columns 3 and 10). Consistent with our results in section 4.3 we also find that most of our findings are driven by affiliates of large groups (columns 4, 5, 11, 12). However, using the panel estimation, the difference between affiliates of specialized and diversified groups is less stark (columns $6,7,13,14)$. Nonetheless, the coefficient on diversified groups is still $15 \%$ to $20 \%$ larger than for specialized groups.

\section{Discussion and conclusion}

This paper uses a comprehensive firm-level database on group affiliation in 15 European countries to study the determinants of group affiliation. Our results indicate that the interaction between financial development and industry demand for external capital affect the formation of corporate groups. We find that even in Western European economies, countries with relatively less developed financial markets have a disproportionately higher percentage of group affiliates in industries with high levels of external dependence. This implies that firms are more likely to be part of corporate groups to access their internal capital markets.

This paper contributes to the broader literature on groups by providing higher resolution on one piece of this eclectic mosaic: European corporate groups. Our results highlight the role that internal capital markets play in the organization decision of firms across nations and industries. We thus directly complement and extend previous research on corporate groups, as well as provide empirical 
evidence for the role of ICM, which may have more general applications in other settings where resource allocation is an important function. An important implication of our study is the finding that capital may be a valuable resource even within developed nations, to the extent that ICM can be more efficient than the prevailing markets for capital.

There is compelling anecdotal evidence in support to our findings. For example, J.P. Morgan (2009) estimates that the portion of total synergies in M\&A transactions attributed to financial resources (such as decreased cost of capital, tax shields, and financial flexibility) increased from $21 \%$ in 2007 to $40 \%$ during the 2008-2009 financial crisis, which reduced the level of financial development for European countries. Consistent with our results, the increase in financial synergies was more pronounced for smaller and less diversified firms with lower credit ratings.

Our findings have several strategic implications. We find that in some countries firms elect to organize into groups despite the many potential costs of group membership, such as governance problems, tax avoidance, market power, and concentrated political influence (Almeida and Wolfenzon, 2005; Cestone and Fumagalli, 2005; Morck, Wolfenzon, and Yeung, 2005). While there are other documented benefits to group membership, our results are strongly consistent with the view that internal capital markets are at least partially driving group association.

This study has also implications for M\&A strategy. First, it may be relevant to firms engaged in the valuation of group-affiliated targets. If separating a target firm from its group deprives it of valuable resources, this may in turn impact its future performance. Second, reliance on ICM may lead group affiliates to maintain less liquidity and reduce market transparency, thus hampering investment and perpetuating market inefficiencies (Teece, et al., 2000). Finally, M\&A is an important mechanism that leads to group affiliation, and this process requires approval by shareholders, who must weigh the pros and cons of remaining independent versus tapping into the resources available to group members. Several notorious cases, such as the protracted negotiations between VW and Porsche or KLM and Alitalia, highlight the importance of appeasing both major and minor shareholders who stand in the way of bringing a firm into a group. Often, stakeholders cannot adequately weigh the trade-offs involved in such a transaction, which calls for better understanding of the less tangible dimensions of group membership.

To the extent that costs and benefits of group membership may vary by nation within the EU, our results highlight the complexity in finding the right balance between shareholder protections, anti-trust policy, and incentives to growth. Similarly, there are potential tensions between individual countries' specific constraints and collective EU goals. Hence it is possible that, even in a very narrowly defined Western European context, no simple answer will arise to the question of whether groups are 
"paragons" or "parasites" (Khanna and Yafeh, 2007).

At a higher level, our work here relates to that which looks at hybrid organizations. Pure forms of hierarchy and markets are becoming increasingly rare, due to the growth of a "swollen" or "swelling" middle (Hennart, 1993). As many have noted, the "old" vertically-integrated mode of production is breaking up, and is being replaced by inter-firm collaboration (Feenstra, 1998, Gilson et al., 2008). Groups may be seen as hybrid forms of organization (Khanna and Yafeh, 2007), and our study may be useful to researchers exploring this type of framework.

\section{References}

[1] Almeida, H.V., and D. Wolfenzon. 2006. A theory of pyramidal ownership and family business groups. The Journal of Finance 61 (6):2637-2680.

[2] Beck, T., A. Demirgüç-Kunt, and R. Levine. 2000. A new database on the structure and development of the financial sector. The World Bank Economic Review 14 (3):597-605. (updated in 2007).

[3] Bratton, W.W., J.A. McCahery, and E.P.M. Vermeulen. 2009. How does corporate mobility affect lawmaking? A comparative analysis. American Journal of Comparative Law 57 (2):347-386.

[4] Carlin, W., and C. Mayer. 2003. Finance, investment, and growth. Journal of Financial Economics 69 (1):191-226.

[5] Carney, M., E.R. Gedajlovic, P.P. Heugens, M. Van Essen, and J.H. Van Oosterhout. 2011. Business group affiliation, performance, context, and strategy: A meta-analysis. The Academy of Management Journal (AMJ) 54 (3):437-460.

[6] Cestone, G., and C. Fumagalli. 2005. The strategic impact of resource flexibility in business groups. RAND Journal of Economics 36 (1):193-214.

[7] Cetorelli, N., and L.S. Goldberg. 2012. Follow the Money: Quantifying Domestic Effects of Foreign Bank Shocks in the Great Recession. National Bureau of Economic Research.

[8] Claessens, S., and L. Laeven. 2003. Financial development, property rights, and growth. The Journal of Finance 58 (6):2401-2436.

[9] Corporate group law for Europe: Comments on the Forum Europaeum's Principles and Proposals for a European Corporate Group Law. European Business Organization Law Review 1: 265-286.

[10] Cremers, K.J.M., R. Huang, and Z. Sautner. 2011. Internal capital markets and corporate politics in a banking group. Review of Financial Studies 24 (2):358-401.

[11] Dahl, D., R.E. Shrieves, and M.F. Spivey. 2002. Financing loan growth at banks. Journal of Financial Services Research 22 (3):189-202. 
[12] De Haas, R., and I. Van Lelyveld. 2010. Internal capital markets and lending by multinational bank subsidiaries. Journal of Financial Intermediation 19 (1):1-25.

[13] Deloof, M. 1998. Internal capital markets, bank borrowing, and financing constraints: evidence from Belgian firms. Journal of Business Finance \& Accounting 25 (7-8):945-968.

[14] Faccio, M., and L.H.P. Lang. 2002. The ultimate ownership of Western European corporations. Journal of Financial Economics 65 (3):365-395.

[15] Feenstra, R.C. 1998. Integration of trade and disintegration of production in the global economy. The Journal of Economic Perspectives 12 (4):31-50.

[16] Fisman, R., and I. Love. 2003. Trade credit, financial intermediary development, and industry growth. The Journal of Finance 58 (1):353-374.

[17] Freeman, J., G.R. Carroll, and M.T. Hannan. 1983. The liability of newness: Age dependence in organizational death rates. American sociological review 48 (5):692-710.

[18] Gertner, R.H., D.S. Scharfstein, and J.C. Stein. 1994. Internal versus external capital markets. Quarterly Journal of Economics 109 (4): 1211-1230.

[19] Gilson, R., C.F. Sabel, and R. Scott. 2008. Contracting for innovation: vertical disintegration and interfirm collaboration. Columbia Law Review, Vol. 109, April 2009, Columbia Law and Economics Working Paper No. 340, ECGI-Law Working Paper No. 118/2009.

[20] Gompers, P.A. 1995. Optimal investment, monitoring, and the staging of venture capital. Journal of Finance 50 (5):1461-1489.

[21] Gopalan, R., V. Nanda, and A. Seru. 2007. Affiliated firms and financial support: Evidence from Indian business groups. Journal of Financial Economics 86 (3):759-795.

[22] Goto, A. 1982. Business groups in a market economy. European Economic Review 19 (1):53-70.

[23] Hennart, J.F. 1993. Explaining the swollen middle: why most transactions are a mix of "market" and "hierarchy." Organization Science 40 (4):529-547.

[24] Khanna, T., and K. Palepu. 2000. Is group affiliation profitable in emerging markets? An analysis of diversified Indian business groups. The Journal of Finance 55 (2):867-891.

[25] Khanna, T., and J.W. Rivkin. 2001. Estimating the performance effects of business groups in emerging markets. Strategic Management Journal 22 (1):45-74.

[26] Khanna, T., and J.W. Rivkin. 2006. Interorganizational ties and business group boundaries: Evidence from an emerging economy. Organization Science 17 (3):333-352.

[27] Khanna, T., and Y. Yafeh. 2005. Business Groups and Risk Sharing around the World. The Journal of Business 78 (1):301-340.

[28] La Porta, R., F. López-de-Silanes, and A. Shleifer. 1999. Corporate ownership around the world. Journal of Finance 54 (2):471-517. 
[29] Levinthal, D.A. 1991. Organizational adaptation and environmental selection-interrelated processes of change. Organization Science. 2 (1):140-145.

[30] Morck, R. 2005. How to Eliminate Pyramidal Business Groups The Double Taxation of Intercorporate Dividends and other Incisive Uses of Tax Policy. MIT Press.

[31] Morck, R., D. Wolfenzon, and B. Yeung. 2005. Corporate Governance, Economic Entrenchment, and Growth. Journal of Economic Literature 43 (3):655-720.

[32] J.P. Morgan. 2009. A Shifting Landscape for Synergies: How Financial Considerations are Affecting Value Creation in Mergers and Acquisitions. Corporate Finance Advisory Publications.

[33] Myers, S.C., and N.S. Majluf. 1984. Corporate financing and investment decisions when firms have information that investors do not have. Journal of Financial Economics 13 (2):187-221.

[34] Nilsen, J.H. 2002. Trade credit and the bank lending channel. Journal of Money, Credit and Banking: 226-253.

[35] Perotti, E.C., and S. Gelfer. 2001. Red barons or robber barons? Governance and investment in Russian financial-industrial groups. European Economic Review 45 (9):1601-1617.

[36] Rajan, R., and L. Zingales. 1998. Financial Dependence and Growth. American Economic Review 88 (3): $559-586$.

[37] Scharfstein, D.S., and J.C. Stein. 2000. The dark side of internal capital markets: Divisional rent-seeking and inefficient investment. The Journal of Finance 55 (6):2537-2564.

[38] Smångs, M. 2006. The nature of the business group: A social network perspective. Organization 13 (6):889-909.

[39] Teece, D.J., R. Rumelt, G. Dosi, and S. Winter. 2000. Understanding corporate coherence. Innovation, organization and economic dynamics: selected essays. 264-293. Edward Elgar Publishing.

[40] Weinstein, D.E., and Y. Yafeh. 1998. On the costs of a bank-centered financial system: Evidence from the changing main bank relations in Japan. The Journal of Finance 53 (2):635-672.

[41] Windbichler, C. 2000. "Corporate Group Law for Europe": Comments on the Forum Europaeum's Principles and Proposals for a European Corporate Group Law. European Business Organization Law Review 1 (02):265-285.

[42] Wulf, J. 2009. Influence and inefficiency in the internal capital market. Journal of Economic Behavior \& Organization 72 (1):305-321. 


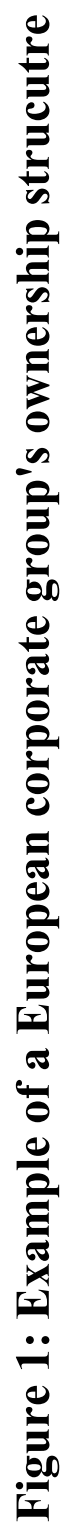

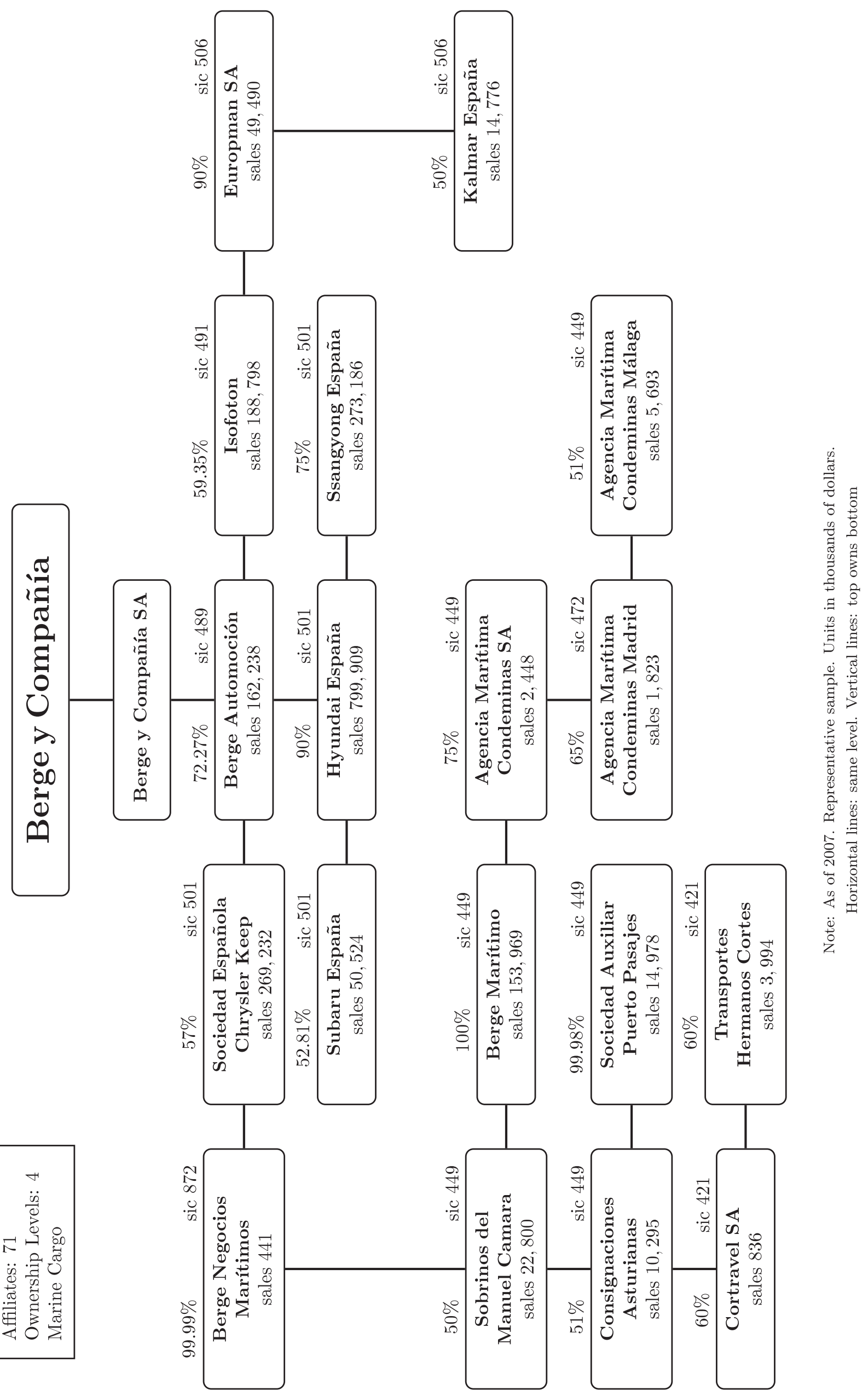




\section{Figure 2: Differences in Group Affiliation between Industries with High and Low External Financial Dependence Across Countries}

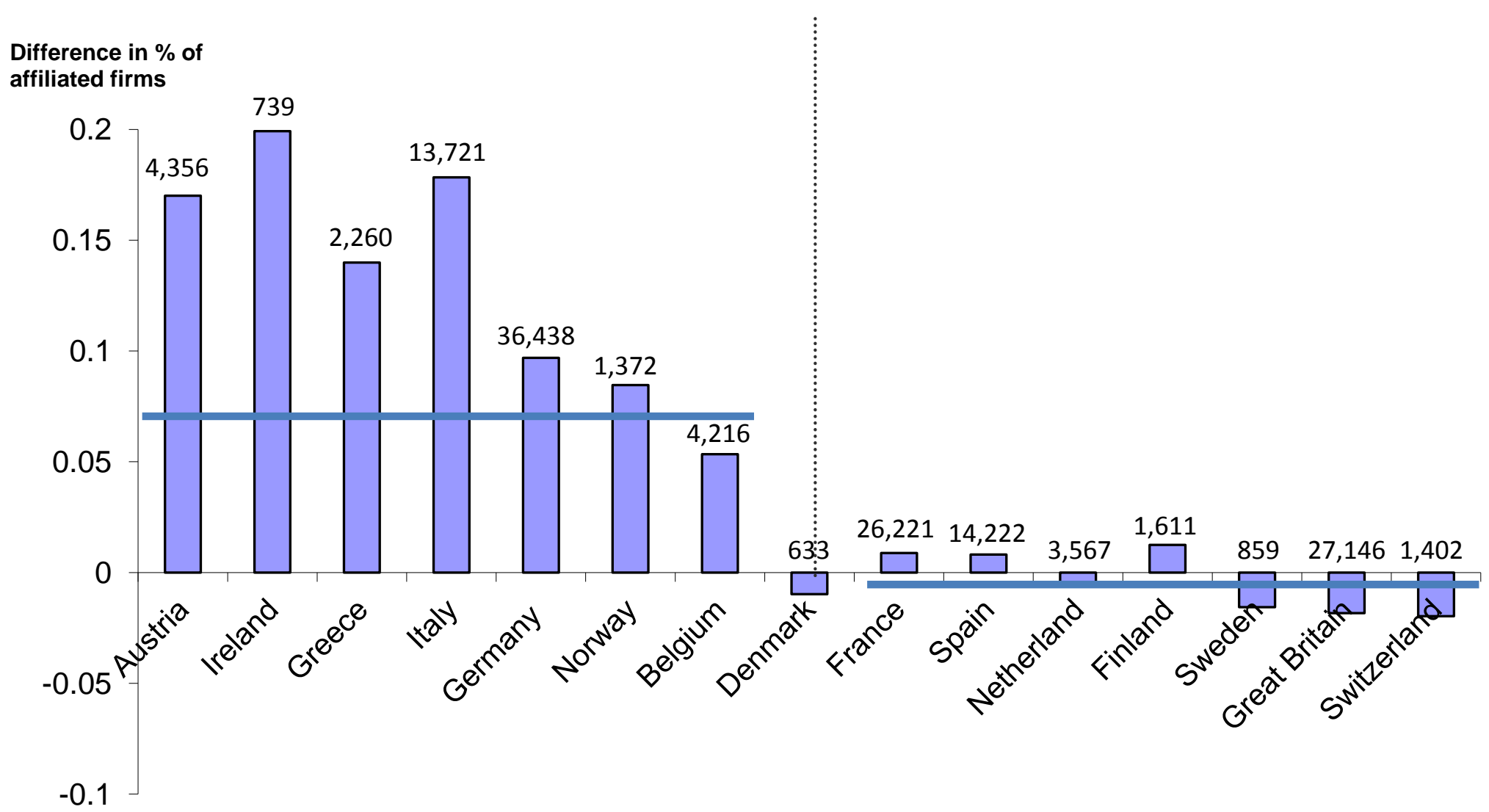

Stock market development

Notes: This figure describes the difference in the percentage of affiliates between the highest and lowest quartiles of external financial dependence across countries. Countries are ranked according to their financial development in ascending order. Financial development is based on Beck et al. (2000, 2007), and is the average of stock market value traded and stock market capitalization over GDP (averaged over the period 2003-2005). External Finance Dependence is computed at the three-digit SIC level based on Compustat firms in 19802004, and is defined as the ratio between capital expenditures minus cash flow from operations and capital expenditures. The number above each bar indicates number of firms. The horizontal lines represent the sample difference in $\%$ of affiliated firms between high and low external dependence for below and above-median country stock market development 
TABLE 1

SUMMARY STATISTICS FOR MAIN FIRM AND GROUP VARIABLES

\begin{tabular}{|c|c|c|c|c|c|c|}
\hline \multirow[b]{2}{*}{ Variable } & \multirow[b]{2}{*}{$\begin{array}{l}\text { \# firms/ } \\
\text { groups }\end{array}$} & \multirow[b]{2}{*}{ Mean } & \multirow[b]{2}{*}{ Std. Dev. } & \multicolumn{3}{|c|}{ Distribution } \\
\hline & & & & $10^{\text {th }}$ & $50^{\text {th }}$ & $90^{\text {th }}$ \\
\hline \multicolumn{7}{|c|}{ Panel A: Firm level } \\
\hline Sales $\left(\$,{ }^{`} 000\right)$ & 138,770 & 172,808 & $2,408,520$ & 11,831 & 27,569 & 181,881 \\
\hline Employess & 122,477 & 392 & 3,919 & 14 & 77 & 478 \\
\hline Assets (\$,000) & 109,129 & 194,489 & $3,135,302$ & 4,988 & 18,593 & 156,511 \\
\hline Firm Age & 133,678 & 25 & 24 & 5 & 18 & 54 \\
\hline Cash Flow (\$, ○00) & 104,116 & 19,584 & 923,785 & -81 & 1,120 & 12,155 \\
\hline \multicolumn{7}{|c|}{ Panel B: Corporate group level } \\
\hline \# of Affiliates & 26,672 & 12 & 40 & 2 & 4 & 21 \\
\hline Sales $(\$, \mathrm{~mm})$ & 26,672 & 2,612 & 28,225 & 20 & 92 & 1,320 \\
\hline Assets $(\$, \mathrm{~mm})$ & 26,672 & 6,521 & 200,710 & 4 & 52 & 995 \\
\hline Cash Flow (\$, mm) & 26,672 & 193 & 3,132 & 0 & 3 & 61 \\
\hline Industry concentration index (HHI) & 26,672 & 0.68 & 0.24 & 0.38 & 0.66 & 1 \\
\hline
\end{tabular}

Notes: This table provides summary statistics on main firm and group variables in the estimation sample. In the upper panel the unit of observation is a firm, and in the lower panel the unit of observation is a corporate group. Firms are included in the estimation sample if they have non-missing sales and ownership information, and generate at least $\$ 10 \mathrm{~mm}$ in annual sales. 
TABLE 2

FIRM CHARACTERISTICS: AFFILIATES VERSUS STANDALONES

\begin{tabular}{|c|c|c|c|c|c|c|c|c|c|}
\hline \multirow[b]{2}{*}{ Variable } & \multirow{2}{*}{$\begin{array}{c}\text { Affiliates - } \\
\text { Standalones }\end{array}$} & \multicolumn{4}{|c|}{ Affiliates } & \multicolumn{4}{|c|}{ Standalones } \\
\hline & & \# firms & Mean & Median & Std. Dev. & \# firms & Mean & Median & Std. Dev. \\
\hline Sales ( 000$)$ & $206,216^{* *}$ & 70,058 & 274,916 & 37,941 & $3,328,597$ & 68,712 & 68,700 & 21,791 & 630,547 \\
\hline Employees & $444^{* *}$ & 63,281 & 607 & 103 & 5,334 & 59,196 & 163 & 58 & 1,124 \\
\hline Assets (`000) & $252,243 * *$ & 61,959 & 303,519 & 25,347 & $4,134,177$ & 47,170 & 51,276 & 13,514 & 506,205 \\
\hline Firm Age & $0.14^{* *}$ & 67,847 & 25.1 & 18 & 23.4 & 65,831 & 24.9 & 18 & 24.1 \\
\hline Cash Flow & $27,977 * *$ & 58,697 & 31,789 & 1,539 & $1,229,523$ & 45,419 & 3,812 & 816 & 46,255 \\
\hline
\end{tabular}

Notes: This table reports mean comparison tests for affiliates and standalones. The unit of observation is a firm. *** implies that the difference in means between affiliates and standalones is significant at the $1 \%$ level. 
TABLE 3

EXTERNAL DEPENDENCE FOR SELECTED INDUSTRIES

\begin{tabular}{|c|c|c|c|c|}
\hline Industry name & $\begin{array}{c}\text { Number of } \\
\text { Firms }\end{array}$ & $\begin{array}{c}\text { External Funds } \\
\text { Dependence } \\
\end{array}$ & Trade Credit & Investment Intensity \\
\hline Chemicals (SIC: 283) & 1,088 & 1.01 & 0.17 & 0.35 \\
\hline Research and development (SIC: 873) & 802 & 0.82 & 0.21 & 0.36 \\
\hline Information technology (SIC: 737) & 4,491 & 0.60 & 0.25 & 0.50 \\
\hline Drugs (SIC: 512) & 2,119 & 0.31 & 0.34 & 0.33 \\
\hline Industry machinery (SIC: 355) & 1,395 & 0.19 & 0.18 & 0.32 \\
\hline Heavy construction (SIC: 162) & 1,066 & 0.09 & 0.17 & 0.33 \\
\hline Rubber and plastic (SIC: 30) & 2,718 & -0.07 & 0.18 & 0.24 \\
\hline Transportation Equipment (SIC: 371) & 1,617 & -0.21 & 0.21 & 0.23 \\
\hline Textille (SIC: 22) & 651 & -0.22 & 0.17 & 0.22 \\
\hline Commercial Printing (SIC: 275) & 1,217 & -0.16 & 0.23 & 0.22 \\
\hline Metals and Minerals (SIC: 505) & 3,346 & -0.31 & 0.24 & 0.17 \\
\hline Concrete (SIC: 327) & 1,063 & -0.34 & 0.11 & 0.18 \\
\hline
\end{tabular}

Notes: This table reports industry external dependence values for selected industries. External Funds Dependence is the difference between capital expenditures minus cash flow from operations over capital expenditures. External Equity Dependence is the net amount of equity issued over capital expenditures. Trade Credit is account receivables over total assets. Investment intensity is the ratio of capital expenditures to total assets. These industry measures are computed at the three-digit SIC code level using Compustat firms for the period 1980-2000. 
TABLE 4

FINANCIAL DEVELOPMENT AND GROUP AFFILIATION

\begin{tabular}{|c|c|c|c|c|c|c|c|c|c|c|c|c|}
\hline \multicolumn{13}{|c|}{ Dependent Variable: Dummy for Group Affiliation } \\
\hline \multirow[b]{2}{*}{ Financial Development: } & (1) & (2) & (3) & (4) & (5) & (6) & (7) & (8) & (9) & (10) & (11) & (12) \\
\hline & \multicolumn{3}{|c|}{ Stock Market Value / GDP } & \multicolumn{3}{|c|}{ Stock Market Capitalization / GDP } & \multicolumn{3}{|c|}{ Private Credit / GDP } & \multicolumn{3}{|c|}{ Bank Deposits / GDP } \\
\hline Industry measure: & $\begin{array}{l}\text { External } \\
\text { Funds } \\
\end{array}$ & $\begin{array}{l}\text { Trade } \\
\text { Credit } \\
\end{array}$ & $\begin{array}{c}\text { Invest } \\
\text { Intensity } \\
\end{array}$ & $\begin{array}{l}\text { External } \\
\text { Funds } \\
\end{array}$ & $\begin{array}{l}\text { Trade } \\
\text { Credit } \\
\end{array}$ & $\begin{array}{c}\text { Invest } \\
\text { Intensity } \\
\end{array}$ & $\begin{array}{l}\text { External } \\
\text { Funds } \\
\end{array}$ & $\begin{array}{l}\text { Trade } \\
\text { Credit } \\
\end{array}$ & $\begin{array}{c}\text { Invest } \\
\text { Intensity } \\
\end{array}$ & $\begin{array}{l}\text { External } \\
\text { Funds } \\
\end{array}$ & $\begin{array}{l}\text { Trade } \\
\text { Credit } \\
\end{array}$ & $\begin{array}{c}\text { Invest } \\
\text { Intensity } \\
\end{array}$ \\
\hline $\begin{array}{l}\text { Financial Development × } \\
\text { Industry }\end{array}$ & $\begin{array}{l}-0.018^{* *} \\
(0.004)\end{array}$ & $\begin{array}{c}-0.108^{* *} \\
(0.019)\end{array}$ & $\begin{array}{c}-0.090^{* *} \\
(0.015)\end{array}$ & $\begin{array}{c}-0.057 * * \\
(0.010)\end{array}$ & $\begin{array}{c}-0.047 * * \\
(0.016)\end{array}$ & $\begin{array}{c}-0.147 * * \\
(0.042)\end{array}$ & $\begin{array}{c}-0.042^{* *} \\
(0.012)\end{array}$ & $\begin{array}{c}-0.254^{* *} \\
(0.063)\end{array}$ & $\begin{array}{c}-0.249 * * \\
(0.049)\end{array}$ & $\begin{array}{c}-0.034^{*} \\
(0.015)\end{array}$ & $\begin{array}{c}-0.325^{* *} \\
(0.080)\end{array}$ & $\begin{array}{c}-0.288^{* *} \\
(0.061)\end{array}$ \\
\hline $\ln ($ Sales ) & $\begin{array}{c}0.101^{* *} \\
(0.001)\end{array}$ & $\begin{array}{c}0.102^{* *} \\
(0.001)\end{array}$ & $\begin{array}{c}0.101^{* *} \\
(0.001)\end{array}$ & $\begin{array}{c}0.101^{* *} \\
(0.001)\end{array}$ & $\begin{array}{c}0.101^{* *} \\
(0.001)\end{array}$ & $\begin{array}{c}0.101^{* *} \\
(0.001)\end{array}$ & $\begin{array}{c}0.101^{* *} \\
(0.001)\end{array}$ & $\begin{array}{c}0.101^{* *} \\
(0.001)\end{array}$ & $\begin{array}{c}0.101^{* *} \\
(0.001)\end{array}$ & $\begin{array}{c}0.101^{* *} \\
(0.001)\end{array}$ & $\begin{array}{c}0.101^{* *} \\
(0.001)\end{array}$ & $\begin{array}{c}0.101^{* *} \\
(0.001)\end{array}$ \\
\hline Industry Sales Share & $\begin{array}{c}-0.714^{* *} \\
(0.141)\end{array}$ & $\begin{array}{c}-0.779 * * \\
(0.142)\end{array}$ & $\begin{array}{c}-0.737 * * \\
(0.141)\end{array}$ & $\begin{array}{c}-0.729 * * \\
(0.141)\end{array}$ & $\begin{array}{c}-0.750^{* *} \\
(0.142)\end{array}$ & $\begin{array}{c}-0.769 * * \\
(0.141)\end{array}$ & $\begin{array}{c}-0.709 * * \\
(0.142)\end{array}$ & $\begin{array}{c}-0.762 * * \\
(0.142)\end{array}$ & $\begin{array}{c}-0.701^{* *} \\
(0.142)\end{array}$ & $\begin{array}{c}-0.734^{* *} \\
(0.141)\end{array}$ & $\begin{array}{c}-0.770 * * \\
(0.142)\end{array}$ & $\begin{array}{c}-0.728^{* *} \\
(0.141)\end{array}$ \\
\hline Country Dummies (15) & Yes & Yes & Yes & Yes & Yes & Yes & Yes & Yes & Yes & Yes & Yes & Yes \\
\hline Three-digit SIC Dummies (163) & Yes & Yes & Yes & Yes & Yes & Yes & Yes & Yes & Yes & Yes & Yes & Yes \\
\hline $\begin{array}{l}\text { Differential in affiliation } \\
\text { probability (\%): }\end{array}$ & -5.9 & -6.5 & -7.8 & -11.9 & -5.9 & -8.1 & -4.0 & -4.4 & -6.2 & -2.6 & -4.5 & -5.7 \\
\hline \% Affiliated & 50.5 & 50.5 & 50.5 & 50.5 & 50.5 & 50.5 & 50.5 & 50.5 & 50.5 & 50.5 & 50.5 & 50.5 \\
\hline Psedu $\mathrm{R}^{2}$ & 0.167 & 0.167 & 0.167 & 0.167 & 0.167 & 0.167 & 0.167 & 0.167 & 0.167 & 0.167 & 0.167 & 0.167 \\
\hline Observations & 138,770 & 138,770 & 138,770 & 138,770 & 138,770 & 138,770 & 138,770 & 138,770 & 138,770 & 138,770 & 138,770 & 138,770 \\
\hline
\end{tabular}

Notes: This table reports the results of Linear Probability Model regressions that examine the effect of financial development on corporate group affiliation. The estimation is cross-sectional (at the firm level) and is based on the 2007 ownership structure. Sales data is for 2006 or the most recent year that data is available. The estimation sample includes firms that have non-missing ownership informations, and annual sale values greater than $\$ 10 \mathrm{~mm}$. Industry Sales Share is three-digit industry sales as a share of total country sales, computed over all firms in the estimation sample. Differential in affiliation probability measures how much higher the likelihood of affiliation is at the 90th percentile level of external dependence with respect to an industry at the 10the percentile level when it is located in a country with the highest level of financial development rather than in one with the lowest level of financial development. Standard errors (in brackets) are robust to arbitrary heteroskedasticity and allow for serial correlation through clustering by ultimate owner (for standalone firms the ultimate owner is the firm itself). * significant at $5 \%$; ** significant at $1 \%$. 
TABLE 5

FINANCIAL DEVELOPMENT AND GROUP AFFILIATION (SURVEY)

\begin{tabular}{|c|c|c|c|c|c|c|c|c|c|c|c|c|}
\hline \multicolumn{13}{|c|}{ Dependent Variable: Dummy for Group Affiliation } \\
\hline \multirow{3}{*}{$\begin{array}{l}\text { Financial Development: } \\
\text { Industry Measure: }\end{array}$} & $(1)$ & $(2)$ & (3) & (4) & $(5)$ & (6) & $(7)$ & $(8)$ & $(9)$ & $(10)$ & $(11)$ & $(12)$ \\
\hline & \multicolumn{3}{|c|}{ Financial System Sophistication } & \multicolumn{3}{|c|}{ Aceess to Venture Capital } & \multicolumn{3}{|c|}{ Aceess to Equity Market } & \multicolumn{3}{|c|}{ Access to Loan Market } \\
\hline & $\begin{array}{l}\text { External } \\
\text { Funds }\end{array}$ & $\begin{array}{l}\text { Trade } \\
\text { Credit }\end{array}$ & $\begin{array}{c}\text { Invest } \\
\text { Intensity }\end{array}$ & $\begin{array}{l}\text { External } \\
\text { Funds }\end{array}$ & $\begin{array}{l}\text { Trade } \\
\text { Credit } \\
\end{array}$ & $\begin{array}{c}\text { Invest } \\
\text { Intensity }\end{array}$ & $\begin{array}{c}\text { External } \\
\text { Funds }\end{array}$ & $\begin{array}{l}\text { Trade } \\
\text { Credit } \\
\end{array}$ & $\begin{array}{c}\text { Invest } \\
\text { Intensity }\end{array}$ & $\begin{array}{l}\text { External } \\
\text { Funds }\end{array}$ & $\begin{array}{l}\text { Trade } \\
\text { Credit } \\
\end{array}$ & $\begin{array}{c}\text { Invest } \\
\text { Intensity } \\
\end{array}$ \\
\hline $\begin{array}{l}\text { Financial Development } \times \\
\text { Industry }\end{array}$ & $\begin{array}{c}-0.027 * * \\
(0.007)\end{array}$ & $\begin{array}{c}-0.110 * * \\
(0.038)\end{array}$ & $\begin{array}{c}-0.120^{* *} \\
(0.031)\end{array}$ & $\begin{array}{c}-0.024 * * \\
(0.007)\end{array}$ & $\begin{array}{c}-0.037 * * \\
(0.012)\end{array}$ & $\begin{array}{c}-0.107 * * \\
(0.031)\end{array}$ & $\begin{array}{c}-0.050 * * \\
(0.015)\end{array}$ & $\begin{array}{c}-0.074^{* *} \\
(0.024)\end{array}$ & $\begin{array}{c}-0.209 * * \\
(0.064)\end{array}$ & $\begin{array}{c}-0.013^{*} \\
(0.006)\end{array}$ & $\begin{array}{c}-0.026 * * \\
(0.010)\end{array}$ & $\begin{array}{c}-0.069 * * \\
(0.025)\end{array}$ \\
\hline $\ln ($ Sales $)$ & $\begin{array}{c}0.101^{* *} \\
(0.001)\end{array}$ & $\begin{array}{c}0.101^{* *} \\
(0.001)\end{array}$ & $\begin{array}{c}0.101^{* *} \\
(0.001)\end{array}$ & $\begin{array}{c}0.100^{* *} \\
(0.001)\end{array}$ & $\begin{array}{c}0.101^{* *} \\
(0.001)\end{array}$ & $\begin{array}{c}0.101^{* *} \\
(0.001)\end{array}$ & $\begin{array}{c}0.101^{* *} \\
(0.001)\end{array}$ & $\begin{array}{c}0.101^{* *} \\
(0.001)\end{array}$ & $\begin{array}{c}0.101^{* *} \\
(0.001)\end{array}$ & $\begin{array}{c}0.101^{* *} \\
(0.001)\end{array}$ & $\begin{array}{c}0.101^{* *} \\
(0.001)\end{array}$ & $\begin{array}{c}0.101^{* *} \\
(0.001)\end{array}$ \\
\hline Industry Sales Share & $\begin{array}{c}-0.709 * * \\
(0.145)\end{array}$ & $\begin{array}{c}-0.746 * * \\
(0.145)\end{array}$ & $\begin{array}{c}-0.730 * * \\
(0.145)\end{array}$ & $\begin{array}{c}-0.705^{* *} \\
(0.145)\end{array}$ & $\begin{array}{c}-0.728 * * \\
(0.145)\end{array}$ & $\begin{array}{c}-0.715^{* *} \\
(0.145)\end{array}$ & $\begin{array}{c}-0.724 * * \\
(0.145)\end{array}$ & $\begin{array}{c}-0.738^{* *} \\
(0.145)\end{array}$ & $\begin{array}{c}-0.735^{* *} \\
(0.145)\end{array}$ & $\begin{array}{c}-0.720^{* *} \\
(0.145)\end{array}$ & $\begin{array}{c}-0.733^{* *} \\
(0.145)\end{array}$ & $\begin{array}{c}-0.722^{* *} \\
(0.145)\end{array}$ \\
\hline Country Dummies (15) & Yes & Yes & Yes & Yes & Yes & Yes & Yes & Yes & Yes & Yes & Yes & Yes \\
\hline Three-digit SIC Dummies (163) & Yes & Yes & Yes & Yes & Yes & Yes & Yes & Yes & Yes & Yes & Yes & Yes \\
\hline $\begin{array}{l}\text { Differential in affiliation } \\
\text { probability (\%): }\end{array}$ & -5.5 & -4.1 & -6.4 & -4.6 & -4.3 & -5.4 & -6.2 & -5.5 & -6.8 & -2.8 & -3.4 & -3.9 \\
\hline$\%$ Affiliated & 50.6 & 50.6 & 50.6 & 50.6 & 50.6 & 50.6 & 50.6 & 50.6 & 50.6 & 50.6 & 50.6 & 50.6 \\
\hline Psedu $\mathrm{R}^{2}$ & 0.166 & 0.166 & 0.166 & 0.166 & 0.166 & 0.166 & 0.166 & 0.166 & 0.166 & 0.166 & 0.166 & 0.166 \\
\hline Observations & 135,877 & 135,877 & 135,877 & 135,877 & 135,877 & 135,877 & 135,877 & 135,877 & 135,877 & 135,877 & 135,877 & 135,877 \\
\hline
\end{tabular}

Notes: This table reports the results of Linear Probability Model regressions that examine the effect of financial development on corporate group affiliation. The estimation is cross-sectional (at the firm level) and is based on the 2007 ownership structure. Sales data is for 2006 or the most recent year that data is available. The estimation sample includes firms that have non-missing ownership informations, and annual sale values greater than $\$ 10 \mathrm{~mm}$. Industry Sales Share is three-digit industry sales as a share of total country sales, computed over all firms in the estimation sample.Differential in affiliation probability measures how much higher the likelihood of affiliation is at the 90th percentile level of external dependence with respect to an industry at the 10the percentile level when it is located in a country with the highest level of financial development rather than in one with the lowest level of financial development. Standard errors (in brackets) are robust to arbitrary heteroskedasticity and allow for serial correlation through clustering by ultimate owner (for standalone firms the ultimate owner is the firm itself). * significant at $5 \%$; ** significant at $1 \%$. 


\section{TABLE 6}

\section{VARIATION BY FIRM AND GROUP CHARACTERISTICS}

Dependent Variable: Dummy for Group Affiliation

\begin{tabular}{|c|c|c|c|c|c|c|c|c|c|c|c|c|}
\hline & $(1)$ & $(2)$ & $(3)$ & $(4)$ & $(5)$ & $(6)$ & $(7)$ & $(8)$ & $(9)$ & $(10)$ & $(11)$ & $(12)$ \\
\hline & \multicolumn{6}{|c|}{ Firm-level } & \multicolumn{6}{|c|}{ Group-level } \\
\hline & \multicolumn{3}{|c|}{ Sales } & \multicolumn{3}{|c|}{ Age } & \multicolumn{3}{|c|}{ Total assets } & \multicolumn{3}{|c|}{ Industry diversification } \\
\hline Sample: & Small & Medium & Large & Young & Middle-age & Mature & Small & Medium & Large & Low & Medium & High \\
\hline $\begin{array}{l}\text { Stock Market Value / GDP } \times \\
\text { External Equity Dependence }\end{array}$ & $\begin{array}{c}-0.021^{* *} \\
(0.008)\end{array}$ & $\begin{array}{c}-0.027 * * \\
(0.005)\end{array}$ & $\begin{array}{l}-0.006 \\
(0.006)\end{array}$ & $\begin{array}{c}-0.013^{*} \\
(0.006)\end{array}$ & $\begin{array}{c}-0.025^{* *} \\
(0.006)\end{array}$ & $\begin{array}{r}-0.000 \\
(0.008)\end{array}$ & $\begin{array}{l}-0.003 \\
(0.003)\end{array}$ & $\begin{array}{c}-0.016^{* *} \\
(0.005)\end{array}$ & $\begin{array}{c}-0.016^{* *} \\
(0.005)\end{array}$ & $\begin{array}{r}-0.008 \\
(0.005)\end{array}$ & $\begin{array}{c}-0.017 * * \\
(0.005)\end{array}$ & $\begin{array}{c}-0.016^{* *} \\
(0.005)\end{array}$ \\
\hline $\ln ($ Sales $)$ & $\begin{array}{c}0.091^{* *} \\
(0.019)\end{array}$ & $\begin{array}{c}0.129 * * \\
(0.005)\end{array}$ & $\begin{array}{c}0.064^{* *} \\
(0.002)\end{array}$ & $\begin{array}{c}0.085^{* *} \\
(0.002)\end{array}$ & $\begin{array}{c}0.107 * * \\
(0.002)\end{array}$ & $\begin{array}{c}0.104^{* *} \\
(0.002)\end{array}$ & $\begin{array}{l}0.001 \\
(0.001)\end{array}$ & $\begin{array}{c}0.087 * * \\
(0.002)\end{array}$ & $\begin{array}{c}0.123^{* *} \\
(0.002)\end{array}$ & $\begin{array}{c}0.071^{* *} \\
(0.002)\end{array}$ & $\begin{array}{c}0.098^{* *} \\
(0.002)\end{array}$ & $\begin{array}{c}0.099 * * \\
(0.003)\end{array}$ \\
\hline Industry Sales Share & $\begin{array}{c}-0.616^{*} \\
(0.272)\end{array}$ & $\begin{array}{c}-0.991 * * \\
(0.203)\end{array}$ & $\begin{array}{l}-0.156 \\
(0.196)\end{array}$ & $\begin{array}{c}-0.514^{*} \\
(0.226)\end{array}$ & $\begin{array}{c}-0.787 * * \\
(0.191)\end{array}$ & $\begin{array}{c}-0.769 * * \\
(0.276)\end{array}$ & $\begin{array}{l}0.049 \\
(0.112)\end{array}$ & $\begin{array}{c}-0.874 * * \\
(0.157)\end{array}$ & $\begin{array}{c}-0.647 * * \\
(0.178)\end{array}$ & $\begin{array}{l}0.025 \\
(0.150)\end{array}$ & $\begin{array}{c}-0.648 * * \\
(0.171)\end{array}$ & $\begin{array}{c}-1.078^{* *} \\
(0.180)\end{array}$ \\
\hline Country Dummies (15) & Yes & Yes & Yes & Yes & Yes & Yes & Yes & Yes & Yes & Yes & Yes & Yes \\
\hline Three-digit SIC Dummies (163) & Yes & Yes & Yes & Yes & Yes & Yes & Yes & Yes & Yes & Yes & Yes & Yes \\
\hline $\begin{array}{l}\text { Differential in affiliation } \\
\text { probability (\%): }\end{array}$ & -6.9 & -8.9 & - & -4.3 & -8.2 & - & - & -5.3 & -5.3 & - & -5.6 & -5.3 \\
\hline \% Affiliated & 36.8 & 47.6 & 69.9 & 51.8 & 50.9 & 53.3 & 7.1 & 36.3 & 27.0 & 18.6 & 32.8 & 23.0 \\
\hline Psedu $\mathrm{R}^{2}$ & 0.141 & 0.130 & 0.105 & 0.142 & 0.163 & 0.227 & 0.051 & 0.141 & 0.284 & 0.098 & 0.151 & 0.227 \\
\hline Observations & 34,698 & 69,380 & 34,692 & 37,267 & 64,030 & 32,381 & 73,981 & 107,919 & 94,066 & 84,438 & 102,235 & 73,981 \\
\hline
\end{tabular}

Notes: This table reports the results of Linear Probability Model regressions examining how the effect of financial development on corporate group affiliation varies by firm and group characteristics. The estimation is cross-sectional (at the firm level) and is based on the 2007 ownership structure. Sales data is for 2006 or the most recent year that data is available. The baseline estimation sample includes firms that have non-missing ownership informations, and annual sale values greater than $\$ 10 \mathrm{~mm}$. Differential in affiliation probability measures how much higher the likelihood of affiliation is at the 90th percentile level of external dependence with respect to an industry at the 10the percentile level when it is located in a country with the highest level of financial development rather than in one with the lowest level of financial development. Standard errors (in brackets) are robust to arbitrary heteroskedasticity and allow for serial correlation through clustering by ultimate owner. * significant at $10 \%$; ** significant at $5 \%$; *** significant at $1 \%$. 
TABLE 7

ROBUSTNESS TESTS

Dependent Variable: Dummy for Group Affiliation. Probit Estimation (marginal effects.)

\begin{tabular}{|c|c|c|c|c|c|c|c|c|c|}
\hline & $(1)$ & $(2)$ & $(3)$ & $(4)$ & (5) & $(6)$ & $(7)$ & $(8)$ & $(9)$ \\
\hline & & & & \multicolumn{3}{|c|}{ Compustat firms } & \multicolumn{3}{|c|}{ Estimation sample } \\
\hline Sample: & All & All & $\begin{array}{c}\text { Excluding } \\
\text { acquired } \\
\text { affiliates }\end{array}$ & $\begin{array}{l}\text { Special- } \\
\text { ized }\end{array}$ & $\begin{array}{c}\text { Below } \\
\text { median } \\
\text { years from } \\
\text { IPO }\end{array}$ & $\begin{array}{c}\text { Above } \\
\text { median } \\
\text { years from } \\
\text { IPO } \\
\end{array}$ & $\begin{array}{l}\text { No } \\
\text { restrictions }\end{array}$ & $\begin{array}{c}\text { Sales }>\$ 1 \\
\mathrm{~mm}\end{array}$ & $\begin{array}{c}\text { Inc. } \\
\text { Missing } \\
\text { ownership }\end{array}$ \\
\hline $\begin{array}{l}\text { Stock Market Value / GDP × } \\
\text { External Equity Dependence }\end{array}$ & $\begin{array}{l}-0.010^{* *} \\
(0.004)\end{array}$ & & $\begin{array}{c}-0.019 * * \\
(0.004)\end{array}$ & $\begin{array}{c}-0.013^{* *} \\
(0.004)\end{array}$ & $\begin{array}{c}-0.017 * * \\
(0.004)\end{array}$ & $\begin{array}{c}-0.018 * * \\
(0.004)\end{array}$ & $\begin{array}{c}-0.024 * * \\
(0.002)\end{array}$ & $\begin{array}{c}-0.018^{* *} \\
(0.003)\end{array}$ & $\begin{array}{c}-0.019 * * \\
(0.003)\end{array}$ \\
\hline \multicolumn{10}{|l|}{$\begin{array}{l}\text { External Equity Dependence, } \\
\text { Interacted: }\end{array}$} \\
\hline 2nd Quartile & & $\begin{array}{c}-0.011^{* *} \\
(0.004)\end{array}$ & & & & & & & \\
\hline 3rd Quartile & & $\begin{array}{c}-0.010 * * \\
(0.004)\end{array}$ & & & & & & & \\
\hline 4th Quartile & & $\begin{array}{c}-0.018 * * \\
(0.004)\end{array}$ & & & & & & & \\
\hline Industry Sales Share & $\begin{array}{l}-1.732 * * \\
(0.108)\end{array}$ & $\begin{array}{c}-0.731^{* *} \\
(0.142)\end{array}$ & $\begin{array}{c}-0.720 * * \\
(0.144)\end{array}$ & $\begin{array}{c}-0.725^{* *} \\
(0.141)\end{array}$ & $\begin{array}{c}-0.705^{* *} \\
(0.141)\end{array}$ & $\begin{array}{c}-0.710^{* *} \\
(0.141)\end{array}$ & $\begin{array}{c}-0.387 * * \\
(0.077)\end{array}$ & $\begin{array}{c}-0.646 * * \\
(0.099)\end{array}$ & $\begin{array}{c}-0.247 * * \\
(0.072)\end{array}$ \\
\hline External Equity Dependence & $\begin{array}{c}0.033^{* *} \\
(0.009)\end{array}$ & & & & & & & & \\
\hline $\ln ($ Sales $)$ & $\begin{array}{c}0.104^{* *} \\
(0.001)\end{array}$ & $\begin{array}{c}0.101 * * \\
(0.001)\end{array}$ & $\begin{array}{c}0.103 * * \\
(0.001)\end{array}$ & $\begin{array}{c}0.101^{* *} \\
(0.001)\end{array}$ & $\begin{array}{c}0.101^{* *} \\
(0.001)\end{array}$ & $\begin{array}{c}0.101^{* *} \\
(0.001)\end{array}$ & $\begin{array}{c}0.075^{* *} \\
(0.001)\end{array}$ & $\begin{array}{c}0.104^{* *} \\
(0.001)\end{array}$ & $\begin{array}{c}0.087 * * \\
(0.001)\end{array}$ \\
\hline Country Dummies (15) & Yes & Yes & Yes & Yes & Yes & Yes & Yes & Yes & Yes \\
\hline Three-digit SIC Dummies (163) & No & Yes & Yes & Yes & Yes & Yes & Yes & Yes & Yes \\
\hline $\begin{array}{l}\text { Differential in affiliation } \\
\text { probability (\%): }\end{array}$ & -3.3 & -5.9 & -6.3 & -4.3 & -5.6 & -5.9 & -9.0 & -5.9 & -5.9 \\
\hline \% Affiliated & 50.5 & 50.6 & 49.9 & 50.5 & 50.5 & 50.5 & 19.4 & 27.0 & 40.5 \\
\hline Psedu $\mathrm{R}^{2}$ & 0.147 & 0.167 & 0.167 & 0.166 & 0.167 & 0.167 & 0.257 & 0.232 & 0.288 \\
\hline Observations & 138,770 & 138,770 & 135,032 & 138,561 & 138,211 & 138,561 & 814,132 & 488,012 & 172,916 \\
\hline $\begin{array}{l}\text { Notes: This table reports the resul } \\
\text { affiliation. The estimation is cross-s } \\
\text { available. Columns } 1-6 \text { include only } \\
\text { Column } 8 \text { includes only firms with s } \\
\text { least } \$ 10 \mathrm{~mm} \text { in sales). Differentials } \\
\text { with respect to an industry at the } 10 \mathrm{t} \\
\text { lowest level of financial developmen } \\
\text { by ultimate owner. * significant at } 5 \%\end{array}$ & $\begin{array}{l}\text { f Linear Prc } \\
\text { onal (at the } \\
\mathrm{ms} \text { with ann } \\
\text { over } \$ 1 \mathrm{~mm} \text {. } \\
\text { ffiliation pro } \\
\text { ercentile leve } \\
\text { tandard error } \\
\text { * significant }\end{array}$ & $\begin{array}{l}\text { bability Mo } \\
\text { irm level) a } \\
\text { dal sales ove } \\
\text { Column } 9 \text { ac } \\
\text { ability meas } \\
\text { when it is l } \\
\text { (in brackets } \\
\text { at } 1 \% \text {. }\end{array}$ & $\begin{array}{l}\text { lel regressiol } \\
\text { id is based o } \\
\text { \$10mm. C } \\
\text { ds firms witl } \\
\text { ure the chan } \\
\text { cated in a cc } \\
\text { ) are robust }\end{array}$ & $\begin{array}{l}\text { s examining } \\
\text { the } 2007 \text { o } \\
\text { lumn } 7 \text { incl } \\
\text { no ownersh } \\
\text { se in likeliho } \\
\text { untry with th } \\
\text { o arbitrary h }\end{array}$ & $\begin{array}{l}\text { the robustr } \\
\text { wnership str } \\
\text { udes all firm } \\
\text { ip informatic } \\
\text { od of affiliat } \\
\text { le highest lev } \\
\text { eteroskedast }\end{array}$ & $\begin{array}{l}\text { ess of the e } \\
\text { ucture. Sales } \\
\text { sith non-r } \\
\text { (classified } \\
\text { ion at the } 90 \\
\text { el of financi } \\
\text { city and allo }\end{array}$ & $\begin{array}{l}\text { ct of financi } \\
\text { ta is for } 200 \\
\text { sing sales an } \\
\text { standalones) } \\
\text { percentile lev } \\
\text { levelopment r } \\
\text { or serial corr }\end{array}$ & $\begin{array}{l}\text { developm } \\
\text { or the mos } \\
\text { ownership } \\
\text { o the baseli } \\
\text { of externa } \\
\text { ther than in } \\
\text { lation throu }\end{array}$ & $\begin{array}{l}\text { nt on group } \\
\text { recent year } \\
\text { information. } \\
\text { he sample (at } \\
\text { dependence } \\
\text { one with the } \\
\text { gh clustering }\end{array}$ \\
\hline
\end{tabular}


TABLE 8

PANEL ESTIMATION: THE FORMATION OF NEWLY ESTABLISHED FIRMS

Dependent Variable: Dummy for Group Affiliation

\begin{tabular}{|c|c|c|c|c|c|c|c|c|c|c|c|c|c|c|}
\hline \multicolumn{15}{|c|}{ Dependent Variable: Dummy for Group Affiliation } \\
\hline & $(1)$ & $(2)$ & (3) & $(4)$ & $(5)$ & $(6)$ & $(7)$ & $(8)$ & $(9)$ & $(10)$ & $(11)$ & $(12)$ & $(13)$ & $(14)$ \\
\hline Financial Development: & \multicolumn{7}{|c|}{ Stock Market Value / GDP } & \multicolumn{7}{|c|}{ Private Credit / GDP } \\
\hline Firms: & All & All & $\begin{array}{l}\text { Sales }> \\
\$ 1 \mathrm{~mm} \\
\end{array}$ & $\begin{array}{c}\text { Small- } \\
\text { group } \\
\text { affiliates }\end{array}$ & $\begin{array}{c}\text { Large- } \\
\text { group } \\
\text { affiliates }\end{array}$ & $\begin{array}{c}\text { Specialized- } \\
\text { group } \\
\text { affiliates } \\
\end{array}$ & $\begin{array}{l}\text { Diversified- } \\
\text { group } \\
\text { affiliates } \\
\end{array}$ & All & All & $\begin{array}{l}\text { Sales> } \\
\$ 1 \mathrm{~mm}\end{array}$ & $\begin{array}{c}\text { Small- } \\
\text { group } \\
\text { affiliates }\end{array}$ & $\begin{array}{c}\text { Large- } \\
\text { group } \\
\text { affiliates }\end{array}$ & $\begin{array}{l}\text { Specialized- } \\
\text { group } \\
\text { affiliates }\end{array}$ & $\begin{array}{c}\text { Diversified- } \\
\text { group } \\
\text { affiliates } \\
\end{array}$ \\
\hline $\begin{array}{l}\text { Financial Development } \times \\
\text { External Equity Dependence }\end{array}$ & $\begin{array}{c}-0.052^{* *} \\
(0.005)\end{array}$ & $\begin{array}{c}-0.047 * * \\
(0.006)\end{array}$ & $\begin{array}{c}-0.040^{* *} \\
(0.008)\end{array}$ & $\begin{array}{l}0.001 \\
(0.002)\end{array}$ & $\begin{array}{c}-0.028 * * \\
(0.005)\end{array}$ & $\begin{array}{c}-0.019 * * \\
(0.004)\end{array}$ & $\begin{array}{c}-0.022^{* *} \\
(0.004)\end{array}$ & $\begin{array}{c}-0.081^{* *} \\
(0.008)\end{array}$ & $\begin{array}{c}-0.091^{* *} \\
(0.011)\end{array}$ & $\begin{array}{c}-0.097^{* *} \\
(0.015)\end{array}$ & $\begin{array}{l}-0.002 \\
(0.005)\end{array}$ & $\begin{array}{c}-0.067 * * \\
(0.011)\end{array}$ & $\begin{array}{c}-0.040^{* *} \\
(0.009)\end{array}$ & $\begin{array}{c}-0.050 * * \\
(0.009)\end{array}$ \\
\hline Industry Sales Share & $\begin{array}{l}0.191 * * \\
(0.076)\end{array}$ & - & - & - & - & - & - & $\begin{array}{l}0.215^{* *} \\
(0.072)\end{array}$ & & & & - & - & - \\
\hline \multicolumn{15}{|l|}{ Fixed-effects: } \\
\hline Country & Yes & - & - & - & - & - & - & - & - & - & - & - & - & - \\
\hline Three-digit SIC & Yes & - & - & - & - & - & - & - & - & - & - & - & - & - \\
\hline Year of Incorporation & Yes & Yes & Yes & Yes & Yes & Yes & Yes & Yes & Yes & Yes & Yes & Yes & Yes & Yes \\
\hline Country $\times$ Industry & No & Yes & Yes & Yes & Yes & Yes & Yes & Yes & Yes & Yes & Yes & Yes & Yes & Yes \\
\hline Psedu R ${ }^{2}$ & 0.116 & 0.137 & 0.150 & 0.128 & 0.137 & 0.065 & 0.120 & 0.123 & 0.144 & 0.152 & 0.136 & 0.140 & 0.066 & 0.125 \\
\hline Observations & 624,115 & 624,115 & 343,122 & 536,436 & 555,937 & 554,491 & 558,060 & 682,260 & 682,260 & 393,105 & 581,100 & 605,312 & 601,951 & 607,518 \\
\hline
\end{tabular}

